\title{
The Relationship Between The Last Wednesday Ritual in The Month of Shafar (Rebo Wekasan) and a False Hadiths Belived by Javanese Muslim
}

\author{
$1^{\text {st }}$ M Ikhsan Tanggok ${ }^{1}$ \\ \{ikhsan.tanggok@uinjkt.ac.id $\left.{ }^{1}\right\}$ \\ UIN Syarif Hidayatullah, Jakarta Indonesia ${ }^{1}$
}

\begin{abstract}
This paper aims to explain the relationship between the last Wednesday ritual in the month of Shafar (rebo wekasan) which is practiced every year by several Javanese Muslims and false hadiths about the month of Shafar. Several Javanese Muslims believe that the last Wednesday in the month of Shafar Allah has reduced various diseases, calamities, and bad luck and if the presence of the month of Shafar is not filled with good practices, then humans will be affected by the calamity revealed by God. This belief is considered by the scholars for not having a strong foundation in both the Koran and the Hadiths of the Prophet Muhammad. Several Muslim communities do not care whether the practices they do have a strong legal basis based on Islamic teachings or do not have a strong foundation. For them to fill the last Wednesday in the month of Shafar with good practices, and with various rituals, is an effort to protect themselves, family members and the community from various kinds of calamities and carry on ancestral traditions. One of the rituals they performed was rebo wekasan, the last Wednesday ritual in the month of Shafar which had been practiced for generations. These rituals-they believe-can prevent them from disasters and calamities that come from God at the last Wednesday in the month of Shafar. Each region in Java has different rituals to celebrate the arrival of the last Wednesday of the Shafar month in accordance with their respective beliefs and cultures.
\end{abstract}

Keywords: Last Wednesday, Ritual, Month of Shafar, False Hadiths, Javanese Muslim.

\section{Introduction}

Several Indonesians, especially Muslims believe that the month of Shafar is an unlucky month, during which Allah decreases all diseases or calamities that can endanger human life. In order that the disease or disaster does not afflict him and his family, then during the coming of the month of Shafar or the second month of the Hijri year many Muslims from various regions of Indonesia perform rituals to prevent them from the disasters that come from Allah. There are several Indonesian Muslims who agree with these rituals and several who disagree. Pros and cons of the Shafar month ritual not only occur in ordinary people, but also occur among the scholars. Those of us who agree that the rituals are our ancestral heritage and we must continue. There are several who disagree with the reason that the rituals in the month of Shafar do not have a strong foundation either in the Koran or in the traditions of the prophet Muhammad. There are several scholars who consider that the traditions relating to the month 
of Shafar, all are weak and cannot be used as a legal basis to justify human actions related to the month of Shafar.

Muslims in Indonesia are not only the pros and cons of the hadiths related to God to bring down the calamity in the month of Shafar, but also the pros and cons of the rituals performed by several Muslims against these traditions. Even so several Muslim communities have already believed that Allah will bring down disasters, whether in the form of diseases or other calamities every year in the month of Shafar.

In Indonesia, especially Muslims, not only does the interpretation of the hadiths of the month of Shafar lead to various rituals, but many other traditions, such as traditions related to nisfu Sya'ban and traditions related to isra 'mi'raj also give birth to various interpretations and also lead to various rituals (Tanggok, 2018). Therefore, in Indonesia, religious teachings must be translated through culture and can only be applied in everyday life in community. It seems that those who perform the rituals do not care whether the rituals they perform have a strong foundation in the Koran and Hadith or not. For this reason, traditions carried down and down and used as a guide in their lives can overcome the rules contained in the Koran and authentic traditions. The purpose of this paper is to examine the relationship between the traditions of the Prophet Muhammad and the rituals related to the month of Shafar. One of the rituals related to the month of Shafar and routinely performed by Javanese people is the rebo wekasan ritual or in West Kalimantan known as the robo-robo ceremony.

\section{Methods}

This study was carried out in several ways: first, conducting a literature review, namely visiting several libraries and researching books related to the hadiths of the month of Rajab. In addition, related to the study of this literature, and also examines the authentic books of Bukhari and Muslims relating to the month of Shafar. In addition, data collection for writing this article also made observations to several areas, such as Mempawah, the Capital of Pontianak Regency and several locations on the island of Java. The purpose of observation is to witness various rituals performed by the people related to the hadiths of the month of Rajab. For data collection needed, in addition to literature studies and observations in the field, I also conducted interviews with Islamic religious leaders, traditional leaders, leaders of the rebo wekasan ceremony, robo-robo and several of the people who carried out the ceremony. The content of the interview is to question the relationship of the ritual they do with the traditions associated with the month of Rajab. The collected data is written in an article and presented. After being presented, this article is revised and then published in a proceeding.

\section{Theoritical Review}

The theory used to explain the relation between rebo wekasan and the hadiths of the month of Shafar, is the theory of ceremonies or rituals. One of Indonesia's anthropology figures who wrote many books on anthropology explained that rituals or ceremonies can be interpreted as a system of activities or a series of actions arranged by custom or law applicable in community that deals with various kinds of events that usually occur in the community concerned (Koentjaraningrat 1990: 190). In contrast to Koentjaraningrat, Haviland (1985: 207) sees that ceremonies are a means that can connect humans with the sacred (holy). He 
considers that this is religion in practice. For him that ritual is not only a means that can strengthen group social ties and reduce tension, but also a way to celebrate important events in daily life. Both the Koentjaraningrat and Haviland theories can be used as a reference in explaining the relationship between Javanese beliefs and the rebuilding ritual.

\section{Literature Review}

In this writing, in addition to oral sources the author also conducts a literature review relating to the writing of this paper. As it is known that research on traditional Javanese ceremonies is done by many experts, so that the existing literature has helped a lot in efforts to write this article. Nevertheless, I have not found many writings that examine specifically about the traditional ceremonies of rebo wekasan in Java. Nevertheless, there are several books that tell about rebo wekasan. The book is titled "Kampung santri: Tatananan dari segi sejarah," and written by Muhammad Fuad Riyadi, Yogyakarta, Itaqa Press, 2001. In this book, rebo wekasan is described as a form of tradition in Javanese community that contains the values of religious and cultural history that must be preserved and preserved. In addition to Riyadi's book (2001), this rebo wekasan can also be seen in a book written by Rifael Raga Maran, entitled Human and Culture in the Perspective of Basic Buddhist Studies. In the book 5 cultural characteristics are described, and one cultural characteristic is that in rebo wekasan that is practiced by the Javanese people has its own characteristics in a process of its implementation and is very different from other traditions in Java.

In addition to books describing rebo wekasan as mentioned above, we also get a little explanation about rebo wekasan from thesis works written by several students, such as Muhammad Dzul Faroh, who wrote thesis with the title "Tradisi Rebo Wekasan di Desa Suci Kecamatan Manyar Kabupaten Gresik dalam Studi Simbol" (2007). This thesis discusses the symbols that exist in the rebo wekasan tradition. As we know, the symbols tell the meanings behind what is seen. In addition to Dzul Faroh's thesis, we can also see an explanation of rebo wekasan in a thesis written by Samsul Aziz (2005) entitled Ceremony Tradition and SocioCultural Change in the people of Garut Cikelet Hamlet. In this thesis, he discusses ceremonial traditions and social change in the hamlet and village communities. This thesis also focuses on the Symbolic Meaning in the tradition of rebo wekasan in Javanese community which is carried on for generations.

In addition to the thesis written by Faroh (2007) and Aziz (2005) we can also see an explanation of rebo wekasan from the thesis written by Umi Nuriatur Rohma (2014). In her thesis, she explains that there is a uniqueness in the practice of the rebo wekasan ritual, one of which is the participants of the ritual writing verses of the Koran on a white porcelain plate, then the plate is dipped in water, and the water is drunk by the participants of the ceremony. This water is efficacious as a deterrent from the disasters that descended on that day. He saw that the practice of writing was called the making of amulets. The verses of the Koran contained in the writing of the amulet are fragments of verses from several surahs from the Koran. The verses are Surah Yasin verse 58, surah al-Shaffat verses 79-80, surah al-Shaffat verses 109-110, al-Shaffat verses 130-131, surah Az-Zumar verse 73, surah al-Ra'd verse 24 and surah al-Qadr verse 5 .

This thesis only focuses on the use of the holy verses of the Koran in the practice of rebo wekasan and does not focus on false traditions that are believed by many people to be associated with the month of Shafar and rebo wekasan. 
An explanation of the rebo wekasan ritual is not only found in books and theses written by students, but can also be found in one article from a journal written by Muhammad Dzofir (2017). The article is titled: "Local Religion and Traditions (Study of the Meaning of the Wekasan Rebo Tradition in Japanese Village, Mejobo, and Kudus)". In his writings, Dzofir focuses his research on the rebo wekasan ritual carried out by the community at the Wali Desa mosque of Japan. In his article, Dzofir explains that the rebo wekasan tradition carried out by the people in the Japanese Village has a very deep meaning about the relationship between humans and their Lord.

In the conclusion of his article, Dzofir explained that the beliefs of Japanese villagers about the arrival of various disasters and disasters in the last Wednesday during the Shafar month were responded by the community by holding religious ceremonies, namely the rebo wekasan tradition at the Wali Desa mosque of Japan. Religious ceremonies are held to ask God, salvation and protection from all the catastrophes and disasters that may occur at the last Wednesday of the Shafar month.

\section{The Shafar Moon Hadith}

The month of Shafar is widely believed by Muslims to be a different month from other months in the Hijri calendar. This month of Shafar is believed by several Muslims to be a month full of disasters, full of calamities and delinquency in them. Therefore many Muslims are afraid of the coming of the month of Shafar and make various rituals to reject what they believe is hereditary. That belief is just a myth because there is no strong legal basis from the texts of the Koran, or the traditions of the Prophet Muhammad.

A remark that is quite popular and is believed to be a hadith that came from the Prophet Muhammad, reads as follows: Rasullullah said "Whoever Informs the News First Shafar To others, then hellfire is forbidden for him."

The words based on the Prophet Shallallahu 'Alaihi Wasallam above have spread widely to the public, and without any information from the creator and the hadith was narrated by whom so as to get to the Prophet Muhammad. This remark has been used as a reference by the community to justify what they did in connection with the last Wednesday in the month of Shafar.

There is no Hadith of the Prophet Muhammad SAW which explains that every month the Shafar Allah will bring various kinds of disasters and bad luck to mankind, and that there is a prophetic tradition about the prohibition of his followers for tathayyur or pessimists with the coming of the month of Shafar. This pessimistic prohibition is found in the authentic AlBukhari hadith, no. 5707 from Abu Hurairah radhiyallahu anhu Prophet Muhammad sallallaahu alayhi wasallam said:

"There is no disease transmission, no tathayyur (pessimistic) with birds, no pessimism with owls, no pessimism (bad luck) with the month of Shafar, and stay away from people with leprosy like staying away from lions."

The Prophet Muhammad's traditions directly refute the belief of several Muslims about the month of Shafar is a month that was revealed by various calamities and diseases. The month of Shafar is the same as the other months in the Hijri year, there is no calamity and bad luck that Allah will send down in it. The belief that the month of Shafar will bring various kinds of calamities, disasters and bad luck, is considered by several scholars as a belief that originated from the ignorant people before Islam. 
Other traditions that oppose the opinion of several people that the month of Shafar is an unlucky month are as follows:

Abu Bakr ibn Abi Shaibah said: Tell us Abu Ahwas, from Simak, from 'Ikrimah, from 'Ibn 'Abbas said: Rasulullah Saw said: "There is no infectious disease, there is no (belief that) the dead person's bones will become birds, and there is no Shafar (unlucky month) month." (This hadith is sourced from Ibn Majah, the book of Tibb ban Man Kana Yu'jibuhu al-Fa'la wa Yakrohu al-Tiyaroh, Hadith no. 3539).

Sayings and beliefs that develop in community about God reduce the unfortunate and unfortunate in the month of Shafar considered by scholars not as a hadith, but the beliefs that came from the Jahiliah before Islam and they considered that belief was not found in the authentic hadith books so they considered it haram to say it came from the Prophet Muhammad. But several Muslim communities in Java, especially those who always fill the coming of the month of Shafar with good practices and practices, do not care whether they do have a strong foundation of hadith or not.

\section{Relationship Between Rebo Wekasan and The Month of Shafar}

Rebo wekasan has a very close relationship with the month of Shafar. Because of human beliefs about the disaster in the month of Shafar, the rebo wekasan ritual is performed. In Javanese community, rebo wekasan is also called rebo pungkasan or rebo kasan. The word rebo wekasan is often used by the people of East Java. While the term rebo pungkasan or rebo kasan is widely used by the people of Central Java and West Java. The term rebo kasan is a fragment of the word term which means the end by adding the front syllable to kasan. Because rebo kasan is the last Wednesday in the month of Shafar, the second month of the Hijri calendar (Umi Nuriatur Rohma, 2014).

The term rebo wekasan, in the Javanese tradition, has a variety of variations, both in terms of their terms and in terms of their meanings that vary according to their respective beliefs. Some people call it rebo wekasan, rebo means Wednesday and wekasan means order. Based on this meaning, the term rebo wekasan means special Wednesday and not like other Wednesdays. Why is that? Because rebo wekasan only happens once a year and the elders or parents advise us to be careful on Wednesday (Zakaria Anshor, 2010: 2, in Muhammad Dzofir, 2017: 112-128). The term rebo wekasan is very easy to understand, because rebo wekasan means the last Wednesday in the month of Shafar, the second month of the Hijri calendar, as mentioned earlier.

The roots of the rebo wekasan tradition actually start from the belief that on the last day of rebuilding in the month of Shafar Allah, all disasters and disasters occur. The above understanding is legitimized by several sources of classical Islamic references, for example the book "Kanzun Najah was-Suraar fi Fadail alAzmina wasy-Syuhaar," by Syech Abdul Hamid al-Quds, which gives a more detailed explanation of the human belief. In the book explained that one Waliyullah who has reached maqom kasyaf (has the ability to see supernatural things) said that in every year God decreases disasters and disasters (Baliyyat) as many as 320,000 (three hundred twenty thousand) kinds in one night. The night coincided with the last Wednesday in the month of Shafar. Based on that Waliyullah gave advice to Muslims to get closer (taqarrub) to Allah and ask for protection to be kept away from all the disasters that were revealed on that day. The Waliyullah gave guidance on the procedure of taqorrub (closeness to Allah) namely by praying which in Javanese terms is better known as a prayer of 
reinforcements. The series of prayers were given by the trustees of God in an effort to ask God to be given salvation and be kept away from disaster (Muhammad Dzofir, 2017: 112-128).

Wekasan rebo is held every last Wednesday in the month of Shafar (Hijri year) which has been a tradition in Indonesian community and has been practiced for generations in Muslim communities in Indonesia. Similar to the celebration of nisfu sa'ban (to welcome the coming of Ramadan) has also become a tradition in Muslim communities in Indonesia for generations and those who carry out this tradition also do not question whether what they do or practice has a strong legal basis in the Koran and Hadith or not. For those who have done good deeds and have been preserved for generations, they must be preserved (Tanggok, 2018). The traditions on the last Wednesday in the month of Shafar which are evenly distributed throughout Indonesia, especially in Muslim communities in Java, as a form of preservation of local culture and can also be used as capital for the region to bring tourists from within the country and can also be used as a tool to improve the regional economy.

The forms of rebo wekasan ritual that many people do include four types, namely:

First, having prayers. Among the prayers that are widely read on the rebo wekasan day are a series of prayers such as those found in the book Kanzun Najah by Abdul Hamid Quds (Abdul Hamid Quds: 26 in Muhammad Dzofir, 2017: 112-128). Second, drinking amulet water. Mentioned in the book Nihayatuz Zain by Imam Nawawi Aljawi Albantani which is a syarah or an explanation of the book of the Fiqh Qurrotul Ain, whoever wrote the seven Salamah verses, namely seven verses of the Koran by reading Salaamun, then the writing is immersed in water, then whoever drinks the water will be saved from the baliyyah (dispatched reinforcement). Third, doing salvation. In several communities in addition to the rituals above, a salvation is also carried out by distributing rice to neighbors and relatives. In several areas the rice was brought to a place such as a mosque or mosque to be enjoyed together. Those who are not able to provide enough rice to bring snacks or drinks. All of those are done as a form of taqorrub to Allah. The form of taqorrub can be done by removing several of its rights or shodaqoh (giving to others voluntarily) in the hope that it can be saved from all disasters. In accordance with the guidance which means that shodaqoh can ward off despair and disasters. Fourth, doing the Sunnah Prayer. Prayers performed in the rebo wekasan are absolute Sunnah prayers, which is Sunnah prayers that are not limited by time, both in terms of the reasons and in terms of their number. This absolute Sunnah prayer is performed on rebo kasan in the framework of taqorrub in order to hope for the safety of Allah SWT (Muhammad Dzofir, 2017: 112-128). It is mentioned in the book Kanzun Najah (Abdul Hamdi Quds: 25-26 in Muhammad Dzofir, 2017: 112-128): "Whoever prays four rokaats, in every rakaat he recites the surah Alfatihah 1X, Al Kautsar 17X, Al Ikhlas 5X, Al Falaq 1X, An Nas 1X, he will be saved from the doom and disaster that Allah sent down on that day."

The last Wednesday activity in the month of Shafar is not only carried out by the Javanese Muslim community, but also carried out by the Malay Muslim community in West Kalimantan, precisely in the Pontianak district and Pontianak City. This ceremony is not called rebo wakesan as a term known on the island of Java, but it is called a robo-robo ceremony. Similar to Javanese Muslims, West Kalimantan Malay Muslims also believe that the last Wednesday in the month of Shafar has spread a lot of calamities, diseases and so on, to avoid themselves and the community from all dangers and disasters, the Malay Muslim community carries out a robo-robo ceremony. The purpose of this ceremony is to avoid the people and people from disasters, diseases and others. This robo-robo event is carried out by providing rhombus food and its side dishes on the porch or in the yard, then family members pray to God to be protected from all disasters and various diseases. This robo-robo ceremony is also performed by offering food to the river watchman spirits and also to the sea watchman 
spirits, so that the fishermen avoid all disasters. This tradition is also enlivened by the rowing competition in Kuala (river) Mempawah and other competitions, so that it can invite many tourists from home and abroad (Tanggok, 2005). Although this event is conducted every year, the Muslim community in West Kalimantan does not care whether the rituals they perform are justified by Islamic teachings or not.

The rebuilding ceremony for the Javanese Muslim community has a fairly long history and has been embedded in people's beliefs. Based on information from the public, the ceremony that was routinely held on Wednesday at the end of the month of Shafar has been around since $1600 \mathrm{AD}$. Although the age of the Shafar month ceremony is quite old, but this ritual is still practiced by Muslims today. This shows that the ceremony during the last week in the month of Shafar was very important for Jawad's Muslim community and Muslim communities outside of Java. In contrast to the last Wednesday activity in the month of Shafar in West Kalimantan, Muslim communities in Java carried out this activity by holding various activities, one of which held a greeting at the mosque or in mosques in villages and even in cities. Some organize it by way of istigosah, reading yasinan, and dhikr or other praise reading and there are also in other forms in accordance with their beliefs of each person and according to their culture. Whatever the Javanese Muslim community does in order to welcome the arrival of the last Wednesday in this month of Shafar, everything is a traditional Javanese ceremony that is different from the traditional ceremonies of other ethnic communities in Indonesia. The purpose of this ceremony is to ask for protection from God in order to avoid all kinds of dangers.

One function of traditional ceremonies is to strengthen the norms and cultural values that have been applied. The norms and values are symbolically displayed through demonstrations in the form of ceremonies performed by all supporting communities. So that the ceremony can arouse a sense of security for every member of the community in his environment, and can also be used as a guide for them in determining their attitudes and daily behavior. The tradition of the rebo wekasan ceremony that is currently experiencing a shift in value, both in its implementation and the value in it. This is a logical consequence of cultural dynamics due to the process of acculturation, changes in mindset and patterns of life of the people.

In addition to the four ways to rebuild the rebo wekasan as mentioned above, the rebo wekasan ceremony also has a unique side to its activities, one of them is writing verses of the Koran on white porcelain plates, then the plates that have been written are dipped in water, and the water is drunk, whose function is to prevent people from the disasters that descend on that day. The practice of writing is referred to as making "amulets". The verses contained in the writing of the amulet are fragments of verses from several surahs in the Koran. The verse is Surah Yaasin 58, Surah al-Shaffat verses 79-80; 109-110, 130-131, Az-Zumar 73, al Ra'd 24, and al-Qadar verse 5 (Umi Nuriaturrahmah, 2014). Amulet is one of the objects used by humans to protect themselves from all kinds of disasters.

The people who carry out the rebo wakesan ritual believe that water that is chanted using the verses of the Koran can keep them away from all the dangers that will befall it. As we know, everyone is afraid of danger, because it can threaten his life, family members and community. They believe that the Koran is not just reading for Muslims, a way of life for Muslims, but also can function as a protector of Muslims from all dangers. One way the Koran can protect humans from all dangers is to spell water with verses of the Koran and the water is used for drinking and bathing. Not all verses of the Koran can be used and suitable to be used as a mantra to reject danger, but only certain verses of the Koran. Water that has been mediated by the verses of the Koran is considered to be sacred (holy) water and water that has not been chant is not considered sacred. 
Javanese community or precisely Javanese tribe, is a person who comes from Javanese descent who in his daily life uses Javanese language with various kinds of dialects for generations. Javanese community is a community bound by the norms of life because of history, tradition and religion (Ismawati, 2002: 85-87). We can say that one of the characteristics of Javanese community is that they are very devout in practicing their religion and also very obedient in carrying out their ancestral traditions. As said by Suwardi Endraswara (2015: 11), Javanese religion is always at the point of perception. That perception will build their religion. Javanese have various perceptions about religion. Sometimes, they don't even know that what they are doing is religious or not. Geertz (1960: 112) explains that one of the characteristics of Javanese people is that they often do slametan (practice for salvation). Changing the house, changing names, starting trips, nightmares, refusing and asking for rain, being sedated, etc. are all related to slametan (carrying out ceremonies, praying, inviting neighbors near and far and eating).

Before the major religions came to Indonesia, especially Java, the Javanese had known and believed in belief in God. God they believe can protect them from all disasters that will befall them. Likewise with the Javanese religious diversity, and religion on Java is increasingly thick with the entry of major religions such as Hinduism, Buddhism, Islam, Catholicism, and Protestantism into Javanese community. In another sense that there are those among them (Javanese) who truly practice the religion of Islam purely in accordance with what is taught in the Koran and the Hadith and which integrate Islamic teachings with ancestral traditions handed down from generation to generation and there are also those who really do not practice Islam correctly. For that we can say that they have synchronized between the teachings of Islam with the teachings of ancestral traditions (Darori, 2002: 85-87). They made this ancestral tradition a way of life other than the teachings of Islam and before Islam entered Java island, they practiced this ancestral tradition for generations.

\section{Conclusions}

From the description of the beliefs of the Javanese people about the last Wednesday in the month of Shafar Allah, lowering all kinds of illnesses and calamities, and the rebuttal of the hadiths on the beliefs of these Muslims, then several conclusions can be drawn:

First, the Muslim community, especially the Javanese people, did not really question whether the rituals they performed (rebo wekasan) related to the arrival of the last Wednesday in the month of Shafar, had a strong legal basis in the Koran and Hadith or not. For them that carrying out the rituals that had been passed down by their ancestors was the same as honoring their previous ancestors. Carrying out the rebo wekasan ritual is the same as making an effort so that he, his family members and the Muslim community as a whole are free from disasters or calamities passed down by God in accordance with their beliefs.

Second, beliefs give birth to rituals and rituals have different functions and meanings for each person or group of people. The meaning and function of the ritual can provide peace of mind for individuals or groups of people who do it.

Third, rebo wekasan in Java and robo-robo ceremonies are two forms of ritual that have different names, the same implementation time and have the same goal so that all humans are free from all the calamities that come at the last Wednesday from the month of Shafar.

Fourth, there is no specific hadith that explains that in the last Wednesday month Shafar Allah has reduced various diseases as is the belief of several Muslim communities in 
Indonesia, especially in Java. There are a number of prophetic traditions that reject the Muslim faith, but these hadiths do not make Muslims not to perform the rituals related to the last Wednesday month of Shafar or the rebo wekasan ritual in Java and the robo-robo ritual in West Kalimantan.

Acknowledgements. This research supported by UIN Syarif Hidayatullah Conference Grant for ICONQUHAS 2019

\section{References}

[1]. Dzofir, Muhammad. Agama dan Tradisi Lokal (Studi Atas Pemaknaan Tradisi Rebo Wekasan di Desa Jepang, Mejobo, Kudus). STAI Kudus Jawa Tengah-Indonesia.

[2]. Geertz, Clifford, 1960. The Religion of Java, New York.

[3]. Koentjaraningrat, 1990. Pengantar Ilmu Antropologi. Jakarta: UI Press.

[4]. Khakim, Fatkhul, 2014. Makna Tradisi Rebo Wekasan di Kecamatan Suradadi Kabupaten Tegal (Skripsi). Semarang: Fakultas Ushuluddin, Institut Agama Islam Negeri Walisongo Semarang.

[5]. Madhan, Khoiri, Makna Simbol Dan Pergeseran Nilai Tradisi Upacara Adat Rebo Pungkasan, Yogyakarta.

[6]. Rohma, Umi Nuriatur, 2014. Penggunaan Ayat-Ayat Al-Quran Dalam Ritual Rebo Wekasan: Studi Living Quran di Desa Sukoreno Kec. Kalisat, Kab. Jember. Fakultas Ushuluddin dan Filsafat, UIN Sunan Kalijaga, Yogyakarta.

[7]. Tanggok M. Ikhsan, 2005. Menembus Birokrasi Indonesia. Jakarta: PT. Gramedia Pustaka Utama

[8]. Ball, J. Van, 1998. Sejarah dan Pertumbuhan Antropologi Budaya: Hingga decade 1970 (History and Growth of Cultural Anthropology: Until the 1970s) (translated by J. Piry). Jakarta: Gramedia.

[9]. Juriyanto, Muhammad. Keutamaan dan Ibadah Malam Nisfu Sha"ban (Primacy and Nisfu Sya'ban Night Worship). Tangerang: Yayasan Pengkajian Hadis El Bukhari Institute.

[10]. Gennap, Arnold van, 1909. The Rites of Passage, (Trans By Monika B. Vizedom and Gabrielle L. Coffe), London: Routlutge and Kengan Paul.

[11]. Neuman, W. Laurence, 1991. Social Research Methods: Qualitative and Quantitative Approaches. USA: Allyin and Bacon.

[12]. Mauss, Marcel, 1954. The Gift: The form and reason for exchange in archaic societies, London and New York: Cohen and West.

[13]. Smith, Charlotte Seymour (1990). Macmillan Dictionary of Anthropology. The Macmillan Press LTD: Hongkong

[14]. Zahra, 2016. Doa dan Amalan di Bulan Rajab, Sha"ban dan Ramadhan (Prayers and Practice on the Month of Rajab, Sha'ban and Ramadan). Jakarta: Zahra. 